\title{
Books Received at the Editorial Office
}

Appearance of a title in this list does not preclude the possibility that a review may appear in a later issue.

D.O. Carpenter: Cellular Pacemakers, vol. 2: Function in Normal and Disease States. Wiley, New York 1982. 371pp., E33.25, bound. ISBN 0-471-09608-3.

R.S. Reneman, A.P.G. Hoeks: Ultrasound in Biome-dicine Research Series, vol. 5: Doppler Ultrasound in the Diagnosis of Cerebrovascular Disease. Wiley, Chichester 1982. XVII + 294 pp., E19.50, bound. ISBN 0-471-10165-6.

A.C.G. Wenink, A. Oppenheimer-Dekker, A.J. Moulaert: The Ventricular Septum of the Heart. Nihjoff, The Hague 1981. XII + 240 pp., Fl. 115.-. ISBN 90-6021-486-2.

B.M. Altura: Advances in Microcirculation, vol. 11:

Ionic Regulation of the Microcirculation. Karger, Basel 1982. X+ 174pp., SFr. 149.-/DM 178.-/ US\$ 89.25, bound. ISBN 3-8055-3429-9.

P. Mathes, M.J. Halhuber (eds): Controversies in Cardiac Rehabilitation. Springer, Berlin 1982. W. Bleifeld (ed): Cardiovascular Disease. International Symposium of the European Society of Cardiology, Hamburg 1981. Thieme, Stuttgart 1982.

M. Kaltenbach, S.E. Epstein (eds): Hypertrophic Car-diomyopathy. The Therapeutic Role of Calcium Antagonists. Springer, Berlin 1982.

H. Roskamm (ed): Myocardial Infarction at Young Age. International Symposium, Bad Krozingen 1981. Springer, Berlin 1981. 